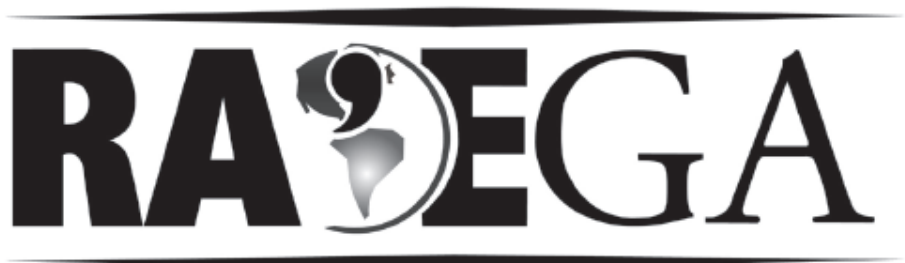

O ESPAÇO GEOGRÁFICO EM ANÁLISE

\title{
OS EFEITOS DA URBANIZAÇÃO NO MICROCLIMA NO BAIRRO MORADA DA SERRA, CUIABÁ - MT
}

\section{THE EFFECTS OF URBANIZATION IN THE MICROCLIMATE IN THE MORADA DA SERRA DISTRICT, CUIABÁ - MT}

\author{
Laura Cristina da Silva VASCONCELOS ${ }^{1}$ \\ Cleusa Aparecida Gonçalves Pereira ZAMPARONI ${ }^{2}$
}

\section{RESUMO}

Os efeitos da urbanização no ambiente geram uma atmosfera local com características climáticas próprias. Assim o objetivo foi analisar o microclima do bairro Morada da Serra, em Cuiabá-MT. Para tanto aplicou-se a metodologia do transecto móvel, coletando dados referentes à temperatura do ar e à nebulosidade às 20h, entre os dias 10 a 16/02/2008 (estação chuvosa) e de 27/07 a 02/08/2008 (estação seca). Recorreu-se também ao índice pluviométrico, além da análise da variação das condições atmosféricas. Quanto a densidade de construções, a temperatura mais alta fixou-se no ponto com ocupação do espaço mais intensa, e a temperatura mais baixa situou-se no ponto localizado sobre um córrego margeado por mata ciliar e onde essa ocupação é rarefeita. Logo, é essencial um planejamento do espaço urbano que apresente soluções para se viver bem num ambiente saudável.

Palavras Chaves: Microclima; urbanização; Cuiabá.

\footnotetext{
1 Geógrafa, Profa. MSc., Depto. Geografia, Universidade Federal de Mato Grosso, Cuiabá - MT, lauravasconcelo@yahoo.com.br

2 Profa. Dra., Depto. de Geografia, Universidade Federal de Mato Grosso, Cuiabá - MT, cazamp@terra.com.br
} 


\section{ABSTRACT}

The effects of urbanization in the environment produce a local atmosphere with individual climatic characteristics. The objective here was to analyze the microclimate in the Morada da Serra district, in Cuiabá-MT. for this, the methodology of the mobile transect was applied, collecting data referring to air temperature and to nebulosity at 20:00 hours, between February 10 and 16, 2008 (rainy season), and between July 27 and August 2, 2008 (dry season). The rainfall indicator was also used, as well as the analysis of the variation of atmospheric conditions. Considering the density of buildings, the highest temperature was fixed at the point with most intense occupation of space, and the lowest temperature was located at a brook with ciliary vegetation, where occupation is less dense. Thus, it is essential to have planned occupation of urban space, presenting solutions for living in a healthy environment.

Key Words: Microclimate; urbanization; Cuiabá.

\section{INTRODUÇÃO}

Segundo Santos; Silveira (2001, p. 389), o processo histórico de urbanização instaurado no território brasileiro a partir do século XVIII sofreu os efeitos da falta de planejamento de suas próprias estruturas administrativas, além de não ter se estendido para toda a população de forma semelhante, homogênea.

De fato, na acepção de Coelho (2004, p. 28), "[...] enquanto a classe alta dispõe de grandes áreas que lhes permitem manter a vegetação e preservar o solo, a classe pobre se aglomera e, ao aumentar a densidade populacional, altera a capacidade de suporte do solo."

De acordo com Moreno (2005, p. 54), em Mato Grosso, especificamente, o processo histórico de ocupação urbana teve início na década de 1940, quando o Estado passou a receber um grande contingente populacional, devido à política de colonização denominada "Marcha para o Oeste".

Na avaliação de Romancini (1996, p. 34-35), Cuiabá, por sua vez, que surgiu em 1719, em decorrência da mineração, só começou a se desenvolver fortemente a partir dos anos 60, em função do forte fluxo migratório estabelecido por ocasião da colonização do Norte do Estado. 
Até a década de 1970, o território da cidade abrangia até a avenida Miguel Sutil, cenário que foi significativamente alterado com o crescimento populacional e a consequente construção do Centro Político Administrativo (CPA), localizado na avenida Historiador Rubens de Mendonça, e destinado ao atendimento dos órgãos públicos estaduais. Sendo assim, o crescimento da cidade passou a apontar para o sentido norte/nordeste.

A área localizada ao norte dessa mesma avenida foi destinada à edificação de conjuntos habitacionais, como, por exemplo, o Morada da Serra, povoado por um segmento populacional de baixo poder aquisitivo, embora se apresente, na atualidade, como uma nova centralidade em relação à cidade. Tanto que, nessa região, podem-se encontrar não só estabelecimentos residenciais, como também comerciais, educacionais, de lazer, saúde, transporte, etc.

Vários estudos sobre climatologia urbana, tanto para as áreas temperadas quanto para as tropicais, provam que os atributos urbanos geram uma atmosfera local com características climáticas próprias, ou seja, temperatura e umidade relativas do ar únicas, diferentes das verificadas nas áreas circunvizinhas.

Buccheri Filho; Nucci (2006, p. 48) avaliam que o crescimento ininterrupto dos espaços urbanizados provoca alterações na paisagem, desequilibrando e prejudicando o meio físico, incluindo o comprometimento da integridade do solo, da água, do ar e dos organismos vivos.

Dessa forma, pesquisas têm demonstrado que a urbanização, devido às transformações na superfície, afeta o clima nas dimensões micro e meso, aumentando a temperatura e, por conseguinte, desorganizando o ciclo das chuvas, o fluxo dos ventos e a umidade relativa do ar.

Na visão de Monteiro (1976, p. 95), "[...] o clima urbano é um sistema que abrange o clima de um dado espaço terrestre e sua urbanização." Para o autor, as consequências das alterações climáticas de origem antrópica são perceptíveis no sistema climático sobretudo das áreas urbanas e expressam-se através dos canais de percepção humana - o do conforto térmico, o da qualidade do ar e o do impacto meteórico -, que se manifestam em eventos 
corriqueiros em especial nas metrópoles, como a poluição do ar, a alteração da ventilação, a configuração de ilhas de calor, o desconforto térmico, o impacto pluvial concentrado, dentre outros.

Esses problemas, agravados por aspectos geoecológicos do sítio, repercutem na qualidade dos serviços sanitários, no desempenho humano, na circulação das pessoas e nos meios de comunicação, sendo capazes de provocar o colapso do sistema urbano, a exemplo do que comumente se verifica no sistema de transportes. Portanto, é difícil proceder à dissociação entre os atributos climáticos e a qualidade ambiental, visto que ambos são aspectos inter-relacionados e interdependentes.

Em face do exposto, o objetivo deste artigo é analisar o microclima do bairro Morada da Serra, a partir da investigação do processo de crescimento urbano da cidade, verificando-se os padrões de densidade de construções, dependentes das condições atmosféricas da região em foco.

\section{PROCEDIMENTOS METODOLÓGICOS}

Foram colhidos dados referentes à temperatura do ar, através do transecto móvel e com o auxílio de um termo-higrômetro (Modelo THAR-185), ambos acoplados a um automóvel, que percorreu os 24 pontos de coleta, previamente selecionados consoante os diferentes padrões de densidade das construções.

A escolha desses pontos de coleta móvel deu-se em função de alguns critérios: a presença ou a ausência de superfície pavimentada, de construções verticais e horizontais; de área residencial; de área comercial; de vegetação de pequeno, médio e grande portes; da presença de corpos d'água (córregos); de solo nu, forrado com gramínea; de praças; além da circulação de veículos e da topografia. Para enriquecer a análise e a discussão dos dados foram coletados, por meio de observação em cada transecto móvel, a situação da nebulosidade, através da cobertura do céu.

Dessa forma, os pontos foram agrupados em três tipos, conforme explicitados na Figura 01 : 
a) Baixa densidade de construções: área com poucas residências, baixa circulação de veículos e muitas árvores, ressaltando-se que em todos os pontos desta categoria foi constante a presença de vegetação, próximo a recursos hídricos (como córregos, lagoas) e a altitude do terreno é média ou baixa,

b) Média densidade de construções: área predominantemente residencial, com média e baixa circulação de veículos e altitude do terreno variando entre média e alta, à exceção do ponto 08, que, apesar de ser uma área comercial, encontra-se fixado sobre um córrego, não canalizado e próximo a uma mata ciliar, cujas presenças, porém, só se percebem atrás das construções, haja vista esse ponto ter sido urbanizado.

c) Alta densidade de construções: área comercial, com alta e média circulação de veículos e altitudes variando entre altas, médias e baixas.

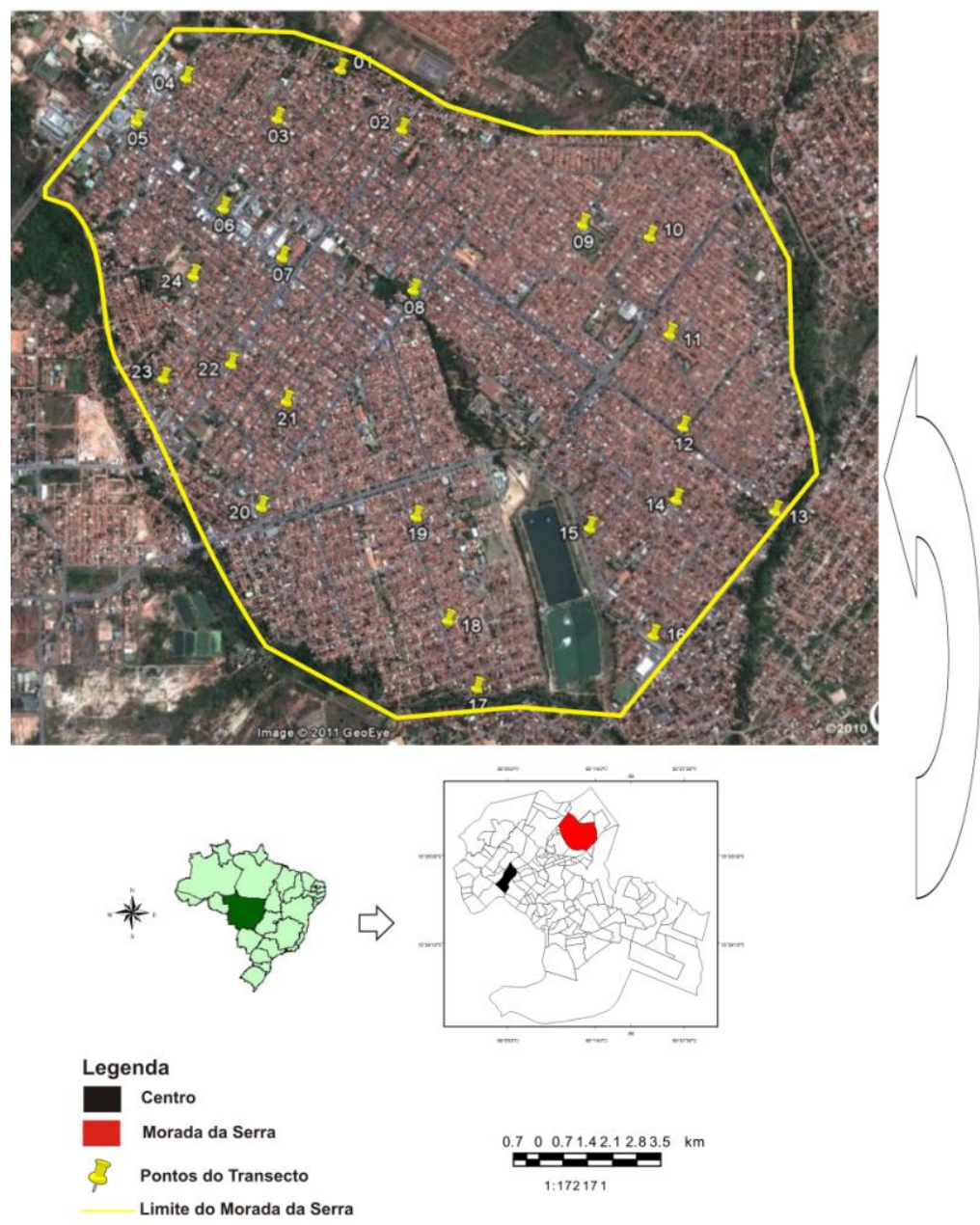

Figura 01: Área urbana de Cuiabá-MT e o bairro Morada da Serra. Org.: VASCONCELOS, 2010. 
Cada transecto móvel durou aproximadamente 40 minutos, todos eles realizados durante sete dias, no período de 10 a 16 de fevereiro de 2008 (estação chuvosa) e de 27 de julho a 02 de agosto de 2008 (estação seca), sempre às $20 \mathrm{~h}$.

Para complementar a análise pluviométrica, utilizou-se, no período chuvoso, uma estação climatológica automática, modelo Davis Weather Monitor II, que foi instalada no Centro Político Administrativo, tendo sido, porém, desativada devido à reforma do prédio. Já no período da seca, fez-se uso de um pluviômetro, assentado em uma residência localizada no bairro Morada da Serra.

A análise da circulação atmosférica da região serviu para todo o período em que se procederam às coletas móveis, por meio das informações fornecidas por imagens de satélites - GOES 10 - e cartas sinóticas elaboradas pelo Instituto Nacional de Pesquisas Espaciais (INPE).

Os dados colhidos foram digitados em um banco de dados e organizados em tabelas elaboradas na planilha eletrônica Excel, após o que foram lançados sob forma de gráficos.

\section{ANÁLISE DAS VARIÁVEIS CLIMÁTICAS NA ESTAÇÃO CHUVOSA}

A partir dos dados coletados no dia 10 de fevereiro de 2008 da estação chuvosa, verificou-se que, às $20 \mathrm{~h}$, o tempo esteve sob a influência da Massa Equatorial Continental, sem chuvas e com o céu limpo, ocorrência muito importante para a caracterização dos atributos da densidade de construções como causas das diferenças nas temperaturas registradas.

A propósito, o maior valor de temperatura indicado foi $29,2^{\circ} \mathrm{C}$, no ponto 08 , e o menor valor foi $28^{\circ} \mathrm{C}$, no ponto 18 , ressaltando-se que essas variáveis atmosféricas referem-se a uma superfície com um padrão médio de densidade de construções: área predominantemente residencial, com média e baixa circulação de veículos e altitudes de 224 m e 197 m, respectivamente.

Entretanto, a temperatura mais elevada pode estar associada à densidade de construções no ponto 08, pois se trata de uma área já ocupada por edificações comerciais e, portanto, já urbanizada, apesar de localizada nas 
proximidades de um córrego e uma mata ciliar, percebidos apenas atrás das construções.

A amplitude térmica do período foi de $1,7^{\circ} \mathrm{C}$.

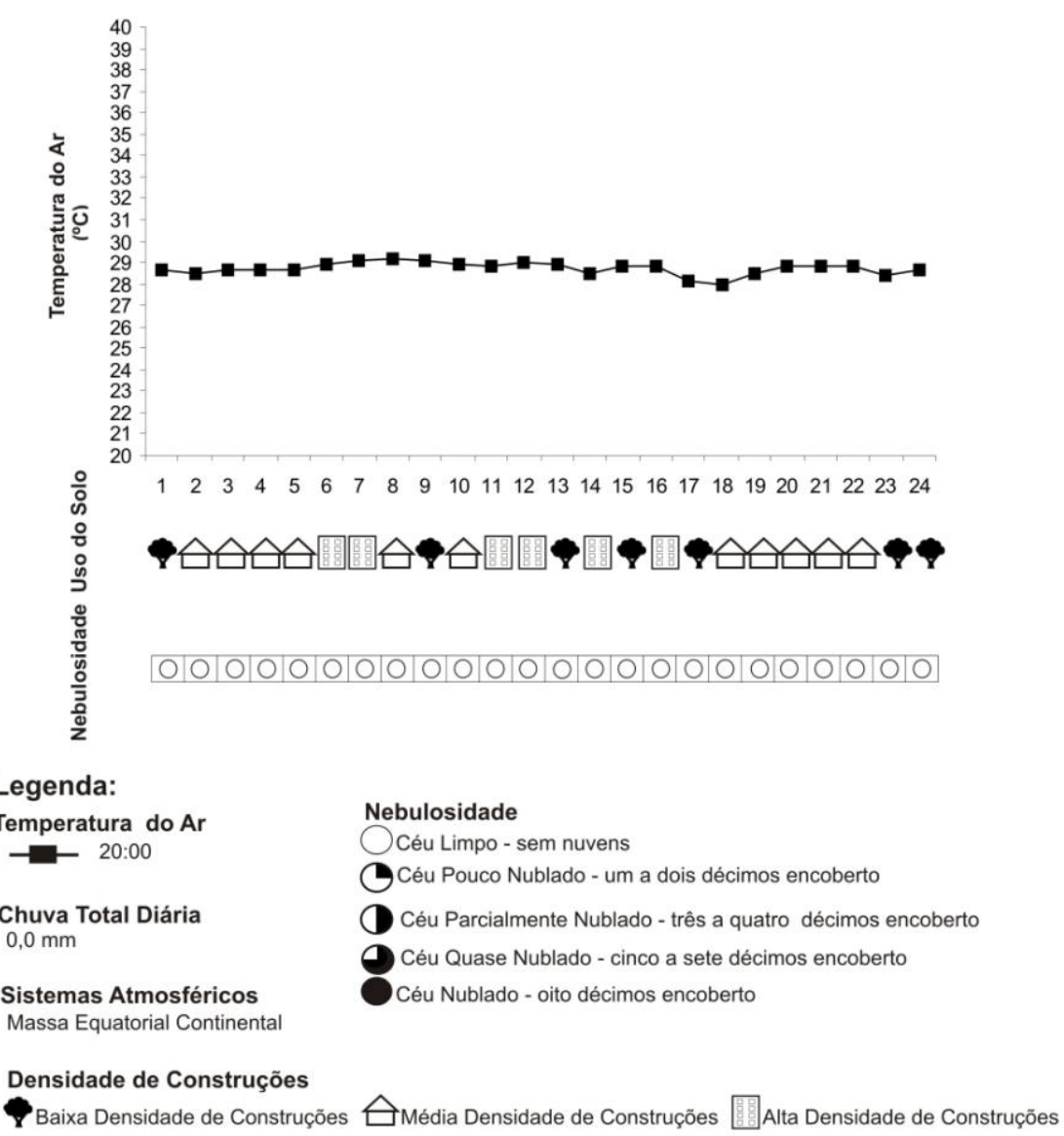

Figura 02: Transecto móvel do dia 10/02/2008.

Org.: VASCONCELOS, 2010.

A Figura 03 resume os dados relativos à coleta do dia 11 de fevereiro de 2008, quando o tempo esteve sob a influência da Massa Tropical Continental, sem chuvas, mas com o céu parcialmente nublado ao longo de todo o percurso, o que pode ter surtido efeitos no comportamento das temperaturas do ar registradas. Além disso, comparativamente aos valores captados no dia 10 de fevereiro, no mesmo horário, pode-se notar a influência da nebulosidade nessa variável climática.

O menor valor de temperatura do $\mathrm{ar}, 24,7^{\circ} \mathrm{C}$, foi apreendido no ponto 18, cuja superfície possui um padrão médio de densidade de construções, constituindo-se numa área residencial, com médio nível de circulação de veículos e uma altitude de $197 \mathrm{~m}$. 
O maior valor de temperatura, $25,2^{\circ} \mathrm{C}$, foi capturado no ponto 01 , localizado em uma área com baixa densidade de construções, aspecto esse expresso pela existência de poucas residências, baixa circulação de veículos e muitas árvores, além da proximidade a recursos hídricos (córregos, lagoas etc.) e da altitude de $216 \mathrm{~m}$.

Nesse caso, ocorre uma situação de inversão na relação entre as temperaturas e os padrões de densidade de construções, já que a temperatura mais alta incide em locais com baixo índice de ocupação do solo e vice-versa. Provavelmente, a explicação para isso se encontra nas condições de nebulosidade que acompanharam todo o percurso da coleta de dados e podem ter mascarado as informações reais.

A amplitude térmica encontrada foi de $0,5^{\circ} \mathrm{C}$, demonstrando que a relação entre as variáveis densidade de construções e comportamento da temperatura do ar é modificada na presença de tempo nublado.

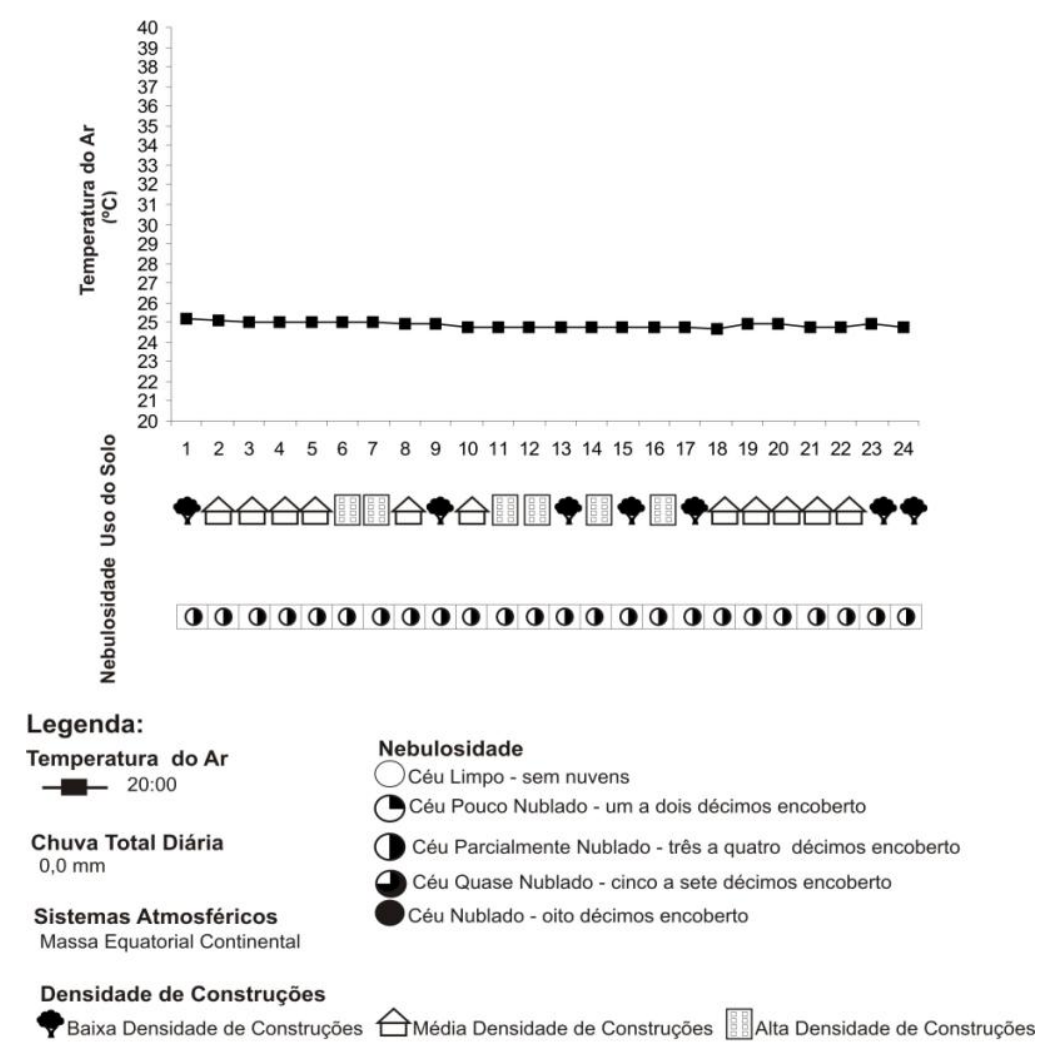

Figura 03: Transecto móvel do dia 11/02/2008.

Org.: VASCONCELOS, 2010. 
A Figura 04 reúne os dados relativos à coleta realizada em 12 de fevereiro de 2008, verificando-se que o tempo esteve sob a influência da Massa Tropical Continental e sem chuvas, mas com o céu pouco nublado durante todo o percurso, o que pode ter interferido no comportamento das temperaturas do ar registrado. Ademais, comparativamente aos valores captados no dia 11 do mesmo mês e no mesmo horário, pode-se notar a influência da nebulosidade nessa variável climática.

O menor valor de temperatura do $\operatorname{ar}, 27,8^{\circ} \mathrm{C}$, foi apreendido no ponto 18, cuja superfície encaixa-se no padrão médio de densidade de construções, constituindo-se numa área residencial com um nível médio de circulação de veículos e uma altitude de $197 \mathrm{~m}$.

Por outro lado, o maior valor de temperatura, $28,4^{\circ} \mathrm{C}$, foi apreendido nos pontos 02, 06, 07 e 08, fixados em áreas com médio e alto padrões de densidade de construções, aspectos esses indicativos, respectivamente, de área residencial, com média circulação de veículos e altitude de $221 \mathrm{~m}$; e de área comercial, com alta circulação de veículos e altitudes variáveis de 224 a $247 \mathrm{~m}$.

Esse caso configura uma situação na qual os valores das temperaturas registradas mesclam-se entre si, contrariando a literatura especializada, que explicita a ocorrência dos menores valores em áreas de alta densidade de construções. Provavelmente, a explicação para isso resida nas condições de nebulosidade que acompanharam todo o percurso da coleta de dados e podem ter mascarado as informações reais.

A amplitude térmica encontrada foi de $0,6^{\circ} \mathrm{C}$, demonstrando que a relação entre as variáveis de densidade de construções e comportamento da temperatura do ar é modificada na presença de tempo nublado. 


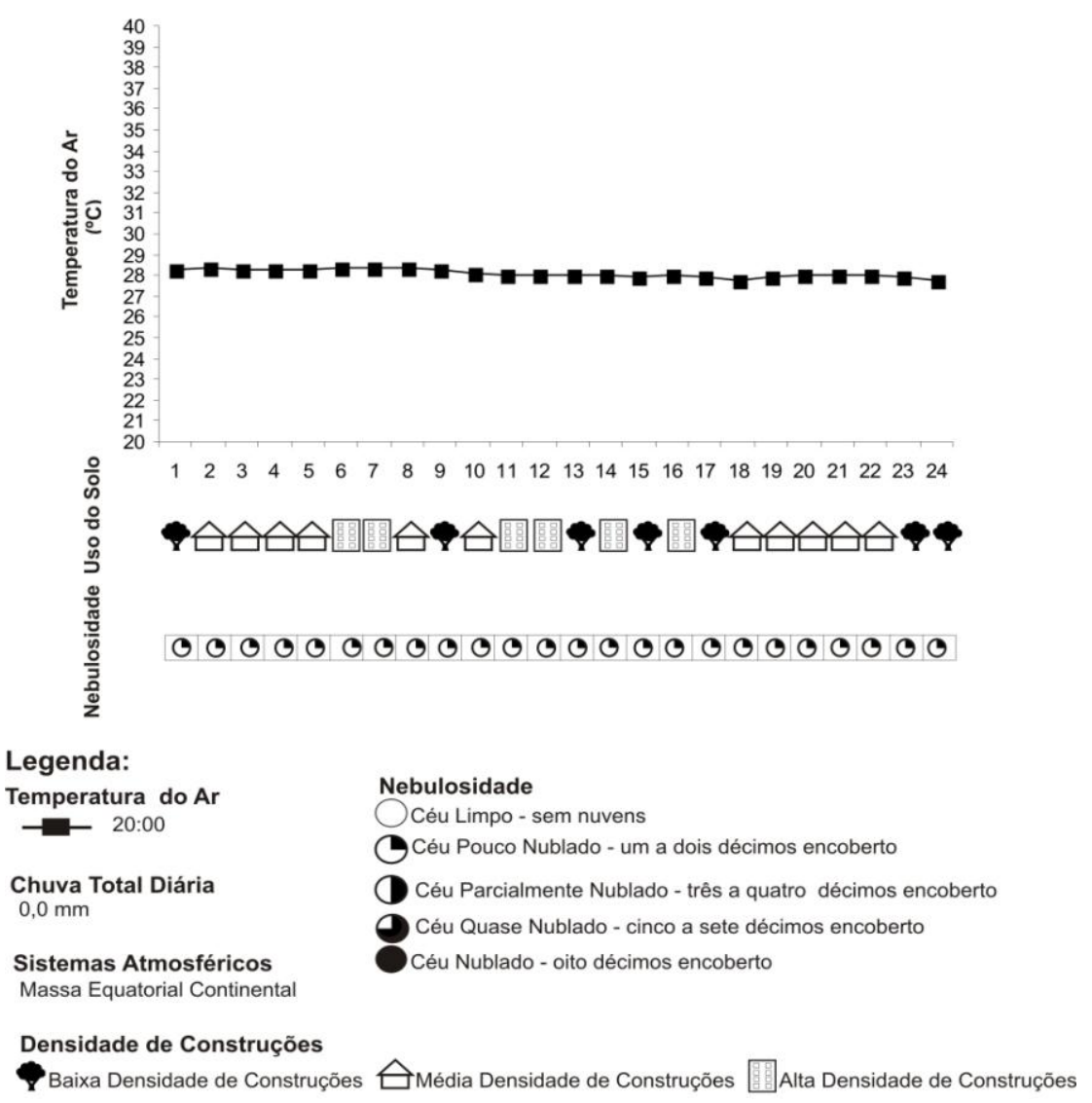

Figura 04: Transecto móvel do dia 12/02/2008.

Org.: VASCONCELOS, 2010.

A Figura 05 congrega os dados referentes à coleta realizada no dia 13 de fevereiro de 2008, quando o tempo esteve sob a influência da Massa Tropical Continental, tendo o céu se apresentado parcialmente nublado ao longo de todo o percurso, e a Estação Climatológica do Centro Político Administrativo, localizada nas proximidades do bairro Morada da Serra, registrou a ocorrência de chuvas, num volume de 59,4 mm entre $18 \mathrm{~h}$ e 19h59min.

Novamente, a presença da nebulosidade pós-chuvas conduz-nos à constatação de que realmente existe influência desse fenômeno no comportamento da temperatura do ar, no sentido de não gerar grandes diferenças entre os maiores e menores valores.

Assim sendo, o menor valor de temperatura do $\operatorname{ar}, 24,2^{\circ} \mathrm{C}$, foi captado no ponto 23 , que apresenta características de uma superfície com baixo padrão 
de densidade de construções, expresso pela presença de residências, baixa circulação de veículos, muitas árvores e altitude de $214 \mathrm{~m}$.

O maior valor da temperatura, $25,4^{\circ} \mathrm{C}$, foi capturado no ponto 01 , também situado em área classificada como sendo de baixo padrão de densidade de construções, apresentando, assim, as mesmas características do ponto 23, no qual foi encontrado o menor valor de temperatura do ar.

Nesse caso, deparou-se com uma situação na qual tanto a maior quanto a menor temperatura ocorrem em locais onde a densidade de construções é considerada baixa. Isso talvez possa ser justificado pelo fato de as chuvas e a nebulosidade que aconteceram anteriormente ao processo da coleta de dados ter interferido na apreensão das informações reais.

Entretanto, a amplitude térmica encontrada no horário das $20 \mathrm{~h}$ foi de $1,2^{\circ} \mathrm{C}$, demonstrando que, mesmo na presença de tempo nublado e de chuvas, os padrões de densidade de construções determinam o comportamento da temperatura do ar na escala local.

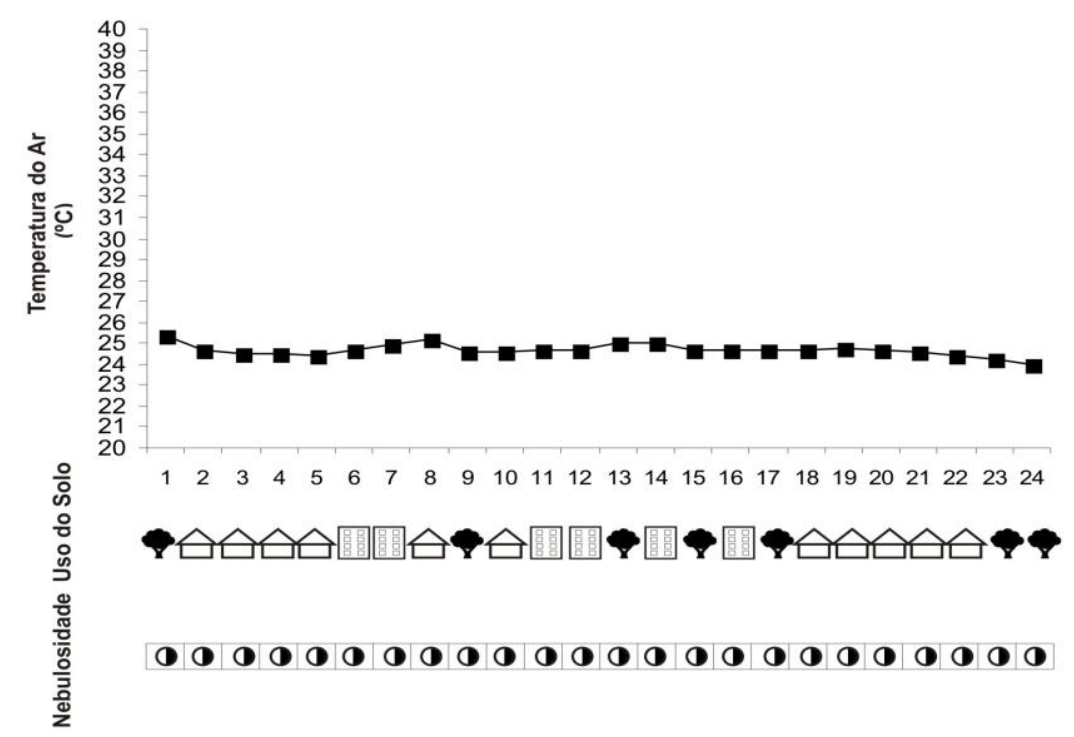

Legenda:

Temperatura do Ar

$\longrightarrow$ 20:00

Nebulosidade

Céu Limpo - sem nuvens

Chuva Total Diária

$59,4 \mathrm{~mm}$

Céu Pouco Nublado - um a dois décimos encoberto

Sistemas Atmosféricos

Massa Equatorial Continental

Céu Parcialmente Nublado - três a quatro décimos encoberto

C Céu Quase Nublado - cinco a sete décimos encoberto

Céu Nublado - oito décimos encoberto

Densidade de Construções

PBaixa Densidade de Construções $\triangle$ Média Densidade de Construções

Figura 05: Transecto móvel do dia 13/02/2008.

Org.: VASCONCELOS, 2010. 
A Figura 06 sintetiza os dados relativos à coleta realizada no dia 14 de fevereiro de 2008 e evidencia que o tempo esteve sob a influência da Massa Equatorial Continental, sem chuvas e com o céu parcialmente nublado durante todo o percurso. Assim sendo, o menor valor de temperatura do ar, $26,6^{\circ} \mathrm{C}$, foi registrado nos pontos 17, 19, 20, 21 e 23, cuja maioria - os pontos 19, 20 e 21 guardava em si mesmas características de áreas com médio padrão de densidade de construções, possuindo área residencial, circulação de veículos com intensidade que oscila de média a baixa e altitudes variando entre 210 e $228 \mathrm{~m}$.

Apenas os pontos 17 e 23 enquadram-se na categoria de áreas que apresentam baixo padrão de densidade de construções, denunciado pela presença de poucas residências, baixa circulação de veículos, muitas árvores, localização próxima a recursos hídricos (córregos, lagoas etc.) e altitudes que flutuam de 182 a $214 \mathrm{~m}$.

Porém, o maior valor de temperatura, $27,8^{\circ} \mathrm{C}$, foi apreendido no ponto 08, superfície em que se verifica um padrão médio de densidade de construções, haja vista ser uma área predominantemente residencial, com média e baixa circulação de veículos e uma altitude de $224 \mathrm{~m}$. Apesar disso, trata-se de um espaço já ocupado por edificações comerciais e, portanto, já urbanizado, ainda que se localize nas proximidades de um córrego e uma mata ciliar, percebidos apenas atrás das construções. Em face dessas descobertas, constata-se que a densidade de construções e a urbanização influenciam o valor da temperatura do ar.

No que se refere ao fato de se ter registrado o menor valor de temperatura do ar em áreas de padrões de densidade de construções classificados como baixo e médio, isso provavelmente se deve às condições de nebulosidade que estiveram presentes ao longo de todo o percurso da coleta de dados e que talvez tenham mascarado as informações reais.

Porém, a amplitude térmica encontrada no horário das $20 \mathrm{~h}$ foi de $1,2^{\circ} \mathrm{C}$, o que, mesmo na presença de tempo nublado, demonstra que o padrão de densidade de construções determina o comportamento da temperatura do ar na escala local. 


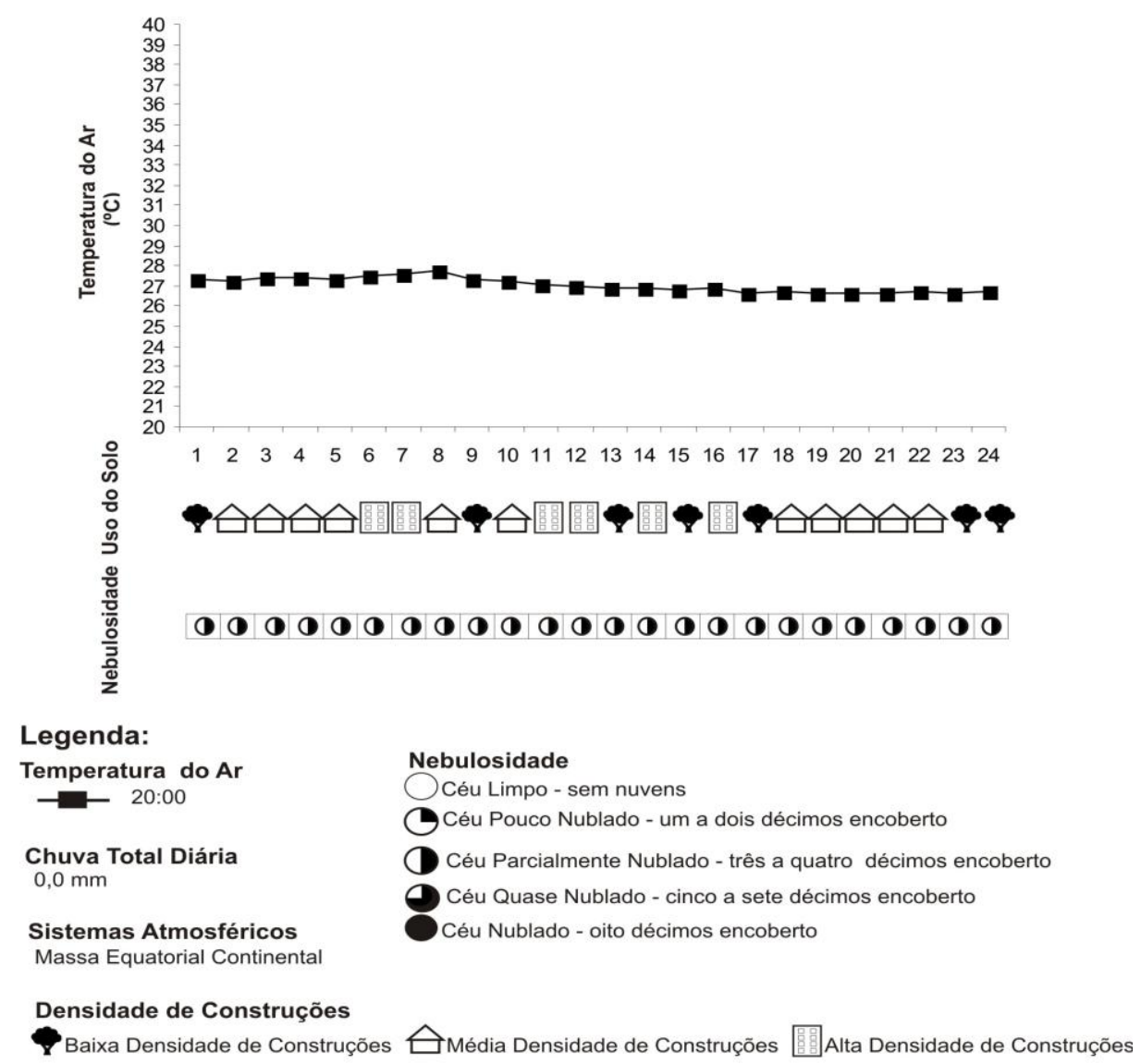

Figura 06: Transecto móvel do dia 14/02/2008.

Org.: VASCONCELOS, 2010.

A Figura 07 exibe os dados relativos à coleta realizada no dia 15 de fevereiro de 2008 e demonstra que o tempo esteve sob a influência da Massa Tropical Continental, encontrando-se o céu parcialmente nublado e tendo a Estação Climatológica do Centro Político Administrativo registrado chuvas, num volume de $22,8 \mathrm{~mm}$, ocorridos entre $16 \mathrm{~h}$ e $17 \mathrm{~h} 59 \mathrm{~min}$. Mais uma vez se constata que a presença da nebulosidade pós-chuvas (que variou de parcial a pouco nublado), na estação chuvosa, pode influenciar o comportamento da temperatura do ar, no sentido de não gerar grandes diferenças entre os maiores e menores valores.

Logo, o menor valor de temperatura do ar, $24,3^{\circ} \mathrm{C}$, foi apreendido no ponto 23, que possui o perfil de uma área com baixo padrão de densidade de construções, expresso pela presença de algumas residências, baixa circulação de veículos, muitas árvores e altitude de $214 \mathrm{~m}$. 
O maior valor de temperatura, $25,1^{\circ} \mathrm{C}$, foi capturado no ponto 01 , também localizado em área classificada como tendo baixo padrão de densidade de construções, evidenciando as mesmas características do ponto 23, no qual foi encontrado o menor valor de temperatura do ar.

Nesse caso, deparou-se com uma situação na qual tanto a maior quanto a menor temperatura ocorrem em locais onde a utilização do solo é considerada baixa. Isso talvez possa ser justificado pelo fato de as chuvas e a nebulosidade que aconteceram durante todo o processo da coleta de dados ter interferido nas informações reais.

Contudo, a amplitude térmica encontrada no horário das $20 \mathrm{~h}$ foi de $1,2^{\circ} \mathrm{C}$, demonstrando que, mesmo na presença de tempo nublado e de chuvas, os padrões de ocupação do solo determinam o comportamento da temperatura do ar na escala local.
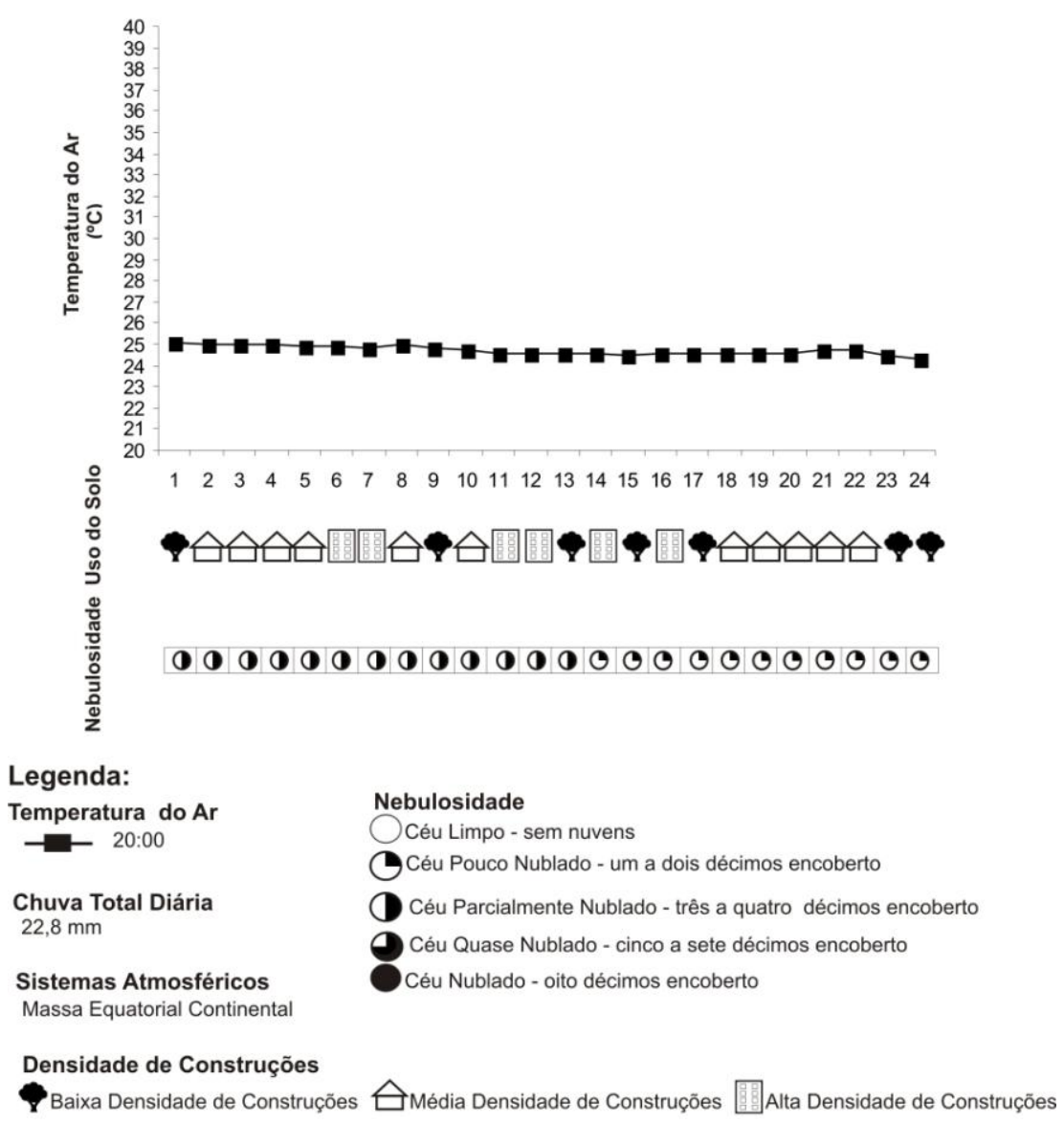

Figura 07: Transecto móvel do dia 15/02/2008.

Org.: VASCONCELOS, 2010. 
A Figura 08 apresenta os dados relativos à recolha efetuada no dia 16 de fevereiro de 2008, verificando-se que o tempo esteve sob a influência da Massa Equatorial Continental e que o céu permaneceu limpo, ocorrência muito importante para a caracterização dos atributos associados aos diversos padrões de densidade de construções como causas das diferenças nas temperaturas registradas.

Além disso, segundo dados da Estação Climatológica do Centro Político Administrativo, houve uma queda de $1 \mathrm{~mm}$ de chuvas ao longo do dia 16 de fevereiro de 2008, entre às $14 \mathrm{~h}$ e $14 \mathrm{~h} 59 \mathrm{~min}$. Quanto ao maior e ao menor valor de temperatura do ar, foram acusados, respectivamente, $27,9^{\circ} \mathrm{C}$, nos pontos 7 e 8 (alto e médio padrões de densidade de construções), e $26,8^{\circ} \mathrm{C}$, no ponto 17 (com baixo padrão de densidade de construções).

A temperatura discretamente mais amena apreendida no ponto 17 deve-se ao fato de estar associada às áreas nas quais se encontram edificados poucos prédios residenciais, há baixa circulação de veículos, existem muitas árvores, localizam-se perto de recursos hídricos (como córregos, lagoas etc.) e apresentam uma altitude de $182 \mathrm{~m}$. Nessa perspectiva, os dados levantados corroboram o que a literatura especializada vem demonstrando: as superfícies com esse tipo de densidade de construções implicam em áreas de temperaturas mais baixas.

Por outro lado, as temperaturas mais elevadas podem ser atribuídas, sobretudo com relação ao ponto 08 , ao fato de se tratar de uma área comercial, embora sua localização, em outras circunstâncias, pudesse ser considerada privilegiada, ou seja, próximo a um córrego e uma mata ciliar, percebidos, porém, apenas atrás das construções.

No tocante à amplitude térmica do período, registrou-se $1,1^{\circ} \mathrm{C}$, revelando que, mesmo na presença de tempo nublado e de chuvas, os padrões de usos do solo determinam o comportamento da temperatura do ar na escala local. 


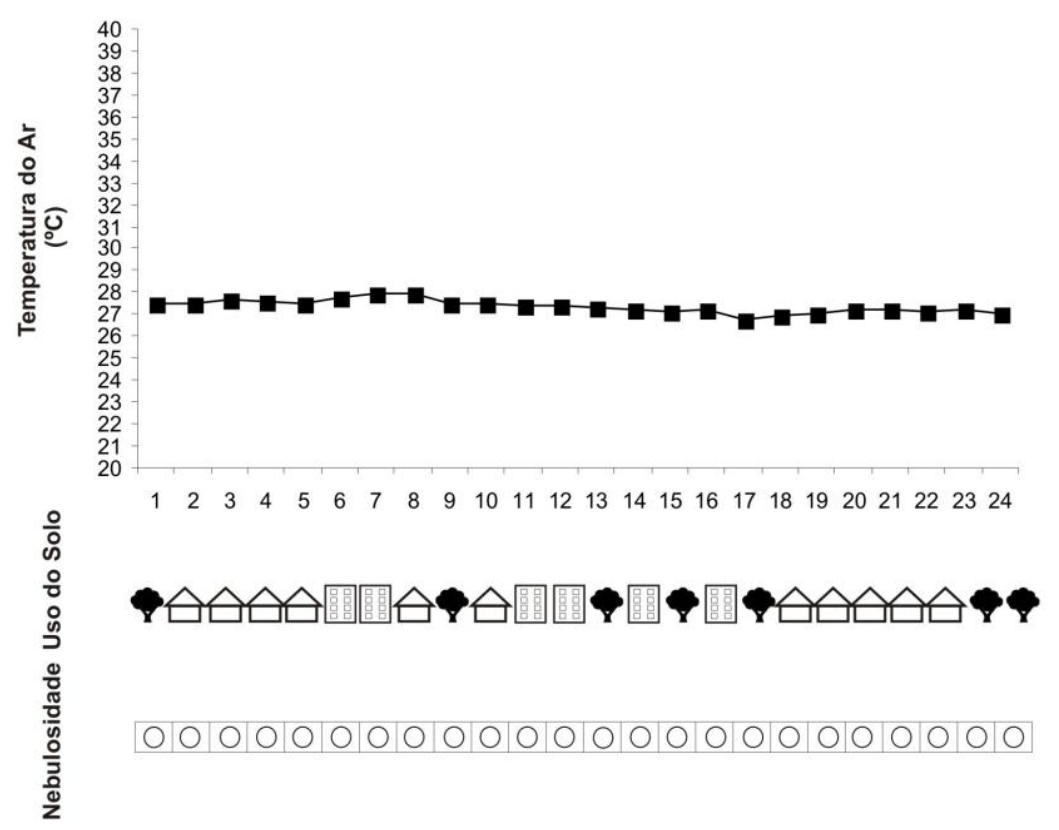

Legenda:

Temperatura do $\mathrm{Ar}$

$\rightarrow$ 20:00

Nebulosidade

Chuva Total Diária

Céu Limpo - sem nuvens

Chuva
$1,0 \mathrm{~mm}$

Céu Pouco Nublado - um a dois décimos encoberto

Sistemas Atmosféricos

Massa Equatorial Continental

(1) Céu Parcialmente Nublado - três a quatro décimos encoberto

( Céu Quase Nublado - cinco a sete décimos encoberto

Céu Nublado - oito décimos encoberto

Densidade de Construções

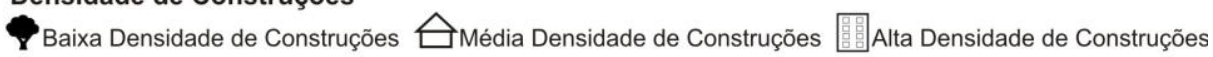

Figura 08: Transecto móvel do dia 16/02/2008.

Org.: VASCONCELOS, 2010.

A análise dos dados climatológicos coletados por meio do transecto móvel no período de 10 a 16 de fevereiro de 2008, durante a estação chuvosa, no bairro Morada da Serra, em Cuiabá-MT, aponta que, mesmo sob a influência de sistemas atmosféricos diferentes, na presença ou ausência de nebulosidade, chuvas e céu limpo, pode-se atribuir o comportamento da temperatura do ar aos diferentes tipos de densidades de construções.

Porém, a ocorrência de nebulosidade e chuvas, típicas da estação chuvosa, pode mascarar informações climatológicas reais na escala local, pois normalmente limpam/ofuscam a atmosfera e neutralizam os efeitos da incidência de radiação solar sobre os diferentes materiais de construção ou da natureza que interferem nas mudanças de variáveis climáticas, como a temperatura do ar. 
Analisando-se os dados referentes à amplitude térmica, nota-se que a menor delas marcou $0,5^{\circ} \mathrm{C}$, no dia 11 de fevereiro, e a maior, $1,4^{\circ} \mathrm{C}$, no dia 13 de fevereiro, sendo que, em ambas as ocasiões, o céu esteve parcialmente nublado.

\section{ANÁLISE DAS VARIÁVEIS CLIMÁTICAS NA ESTAÇÃO SECA}

A Figura 09 exibe os dados relativos à coleta a qual se procedeu no dia 27 de julho de 2008, na estação seca, demonstrando que o tempo esteve sob a influência da Massa Tropical Continental, apresentando céu limpo e ausência de chuvas, o que é muito importante para se atribuir aos padrões de usos do solo as diferenças de temperaturas encontradas e associar com maior nitidez a influência do tipo de densidade de construções nas variáveis climáticas.

Portanto, a temperatura mais alta acusou $29^{\circ} \mathrm{C}$ no ponto 07 , inserido na categoria de alto padrão de densidade de construções, haja vista corresponder a uma área comercial, na qual se verifica intenso fluxo de veículos e uma altitude de $242 \mathrm{~m}$. Por outro lado, a temperatura mais baixa indicou $24^{\circ} \mathrm{C}$ no ponto 17, correspondente ao perfil de uma área em que há baixo padrão de densidade de construções e que reúne em sua superfície edificações residenciais, dispostas próximo a um córrego e de uma mata ciliar, havendo ali, ainda, baixa circulação de veículos e uma altitude de $182 \mathrm{~m}$. Isso implica que, apesar das diferenças de temperatura entre os dois pontos, elas são altamente significativas e expressam as consequências da interferência dos níveis de densidade de construções no comportamento das temperaturas do ar.

Então, a amplitude térmica do período foi de $5^{\circ} \mathrm{C}$, confirmando $\mathrm{o}$ caráter determinante dos tipos de ocupação do solo sobre o comportamento da temperatura do ar na escala local. 


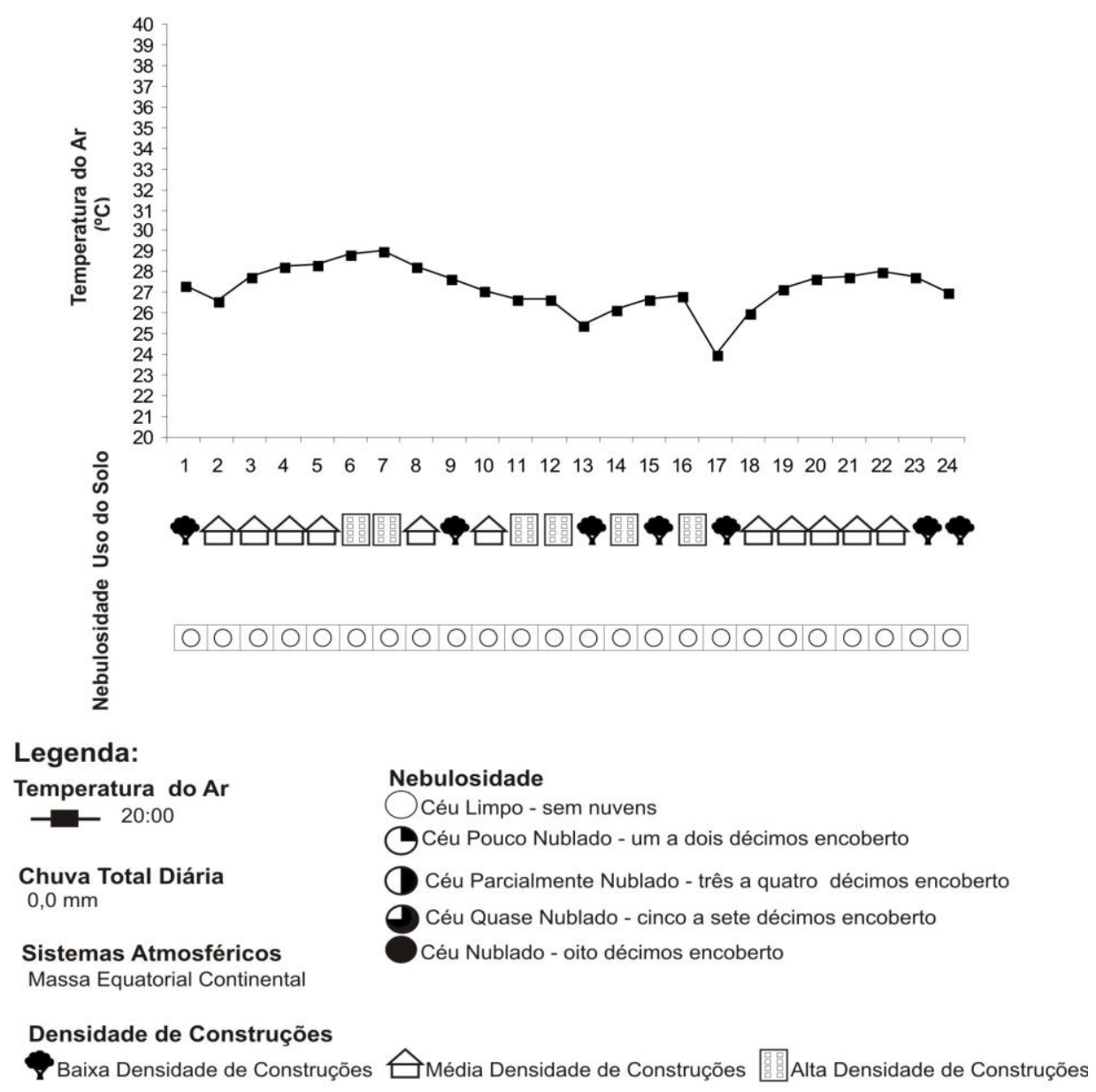

Figura 09: Transecto móvel do dia 27/07/2008.

Org.: VASCONCELOS, 2010.

A Figura 10 agrupa os dados da coleta efetuada no dia 28 de julho de 2008, mostrando que o tempo esteve sob a influência da Massa Tropical Continental, com céu limpo e isenção de chuvas, tendo-se registrado o maior valor de temperatura do $\operatorname{ar}, 28,8^{\circ} \mathrm{C}$, no ponto 07 , que se encaixa na categoria de alto padrão de densidade de construções, haja vista ser uma área comercial, com alta circulação de veículos e altitude de $242 \mathrm{~m}$.

Já o menor valor de temperatura do $\operatorname{ar}, 23,5^{\circ} \mathrm{C}$, foi indicado no ponto 17, condizente com a categoria de baixo padrão de densidade de construções, pois se constitui numa superfície ocupada por poucas residências, com baixa circulação de veículos, muitas árvores, próxima a recursos hídricos (como córregos, lagoas etc.) e altitude de $182 \mathrm{~m}$. 
Com relação à amplitude térmica registrada, $5,3^{\circ} \mathrm{C}$, pode-se afirmar a interferência do tipo de densidade de construções no comportamento dessa variável climática na escala local.

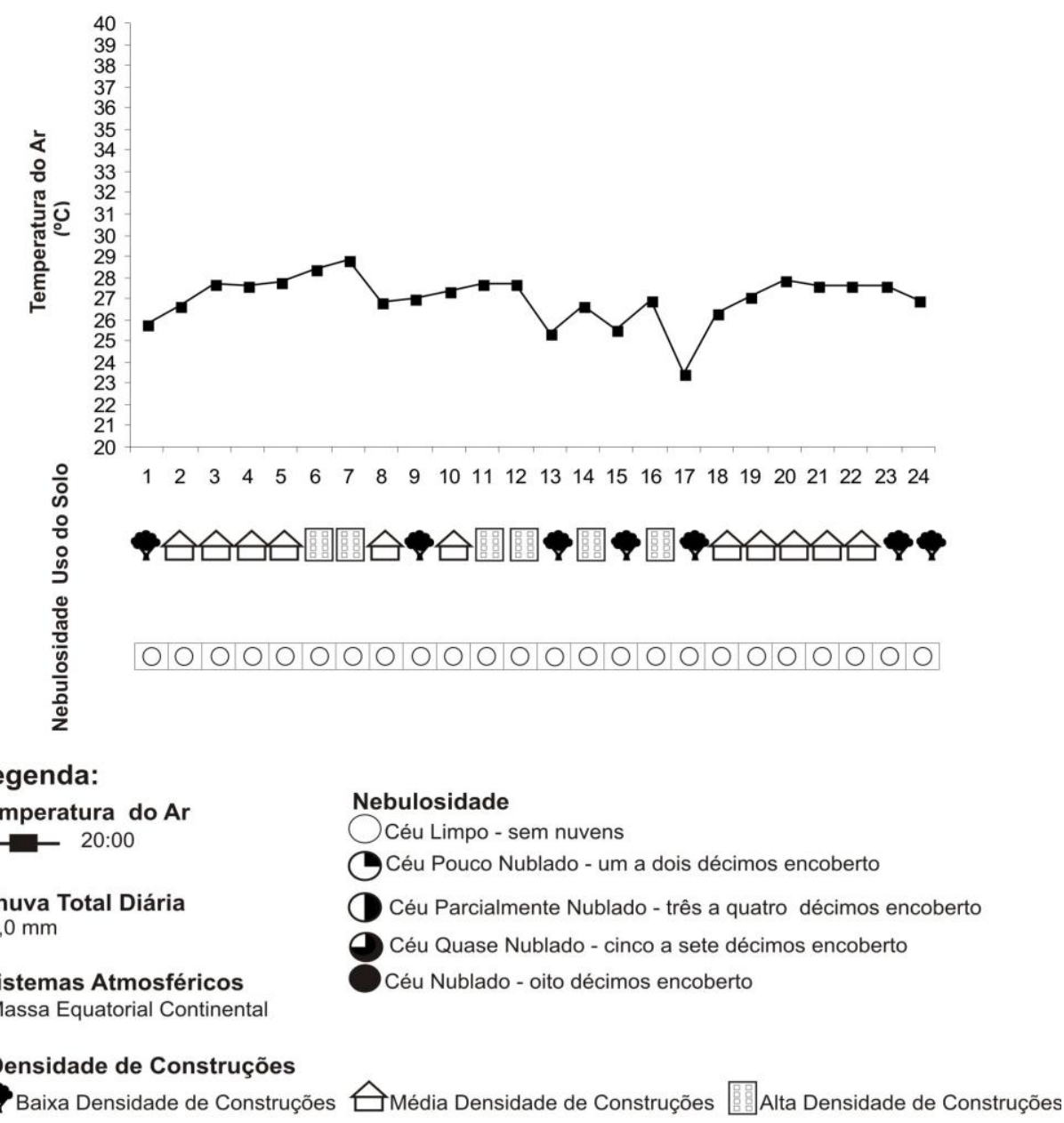

Figura 10: Transecto móvel do dia 28/07/2008.

Org.: VASCONCELOS, 2010.

A Figura 11 congrega os dados relativos à coleta efetuada no dia 29 de julho de 2008, mostrando que o tempo esteve sob a influência da Massa Tropical Continental, com céu limpo e isenção de chuvas. Nesse trajeto, o maior valor de temperatura do ar, $28,8^{\circ} \mathrm{C}$, foi detectado nos pontos 06 e 07 , inseridos na categoria de alto padrão de densidade de construções, por se constituir numa área comercial, com alta circulação de veículos e uma altitude que varia de 242 a $247 \mathrm{~m}$. 
Enquanto isso, o menor valor de temperatura do $\operatorname{ar}, 24,2^{\circ} \mathrm{C}$, foi detectado no ponto 17, correspondendo à categoria de baixo padrão de densidade de construções, já que é uma superfície ocupada por poucas residências, com baixa circulação de veículos, muitas árvores, próxima a recursos hídricos (como córregos, lagoas etc.) e altitude de $182 \mathrm{~m}$.

Quanto à amplitude térmica registrada, $4,6^{\circ} \mathrm{C}$, esse dado é expressivo da interferência do tipo de densidade de construções no comportamento dessa variável climática na escala local.

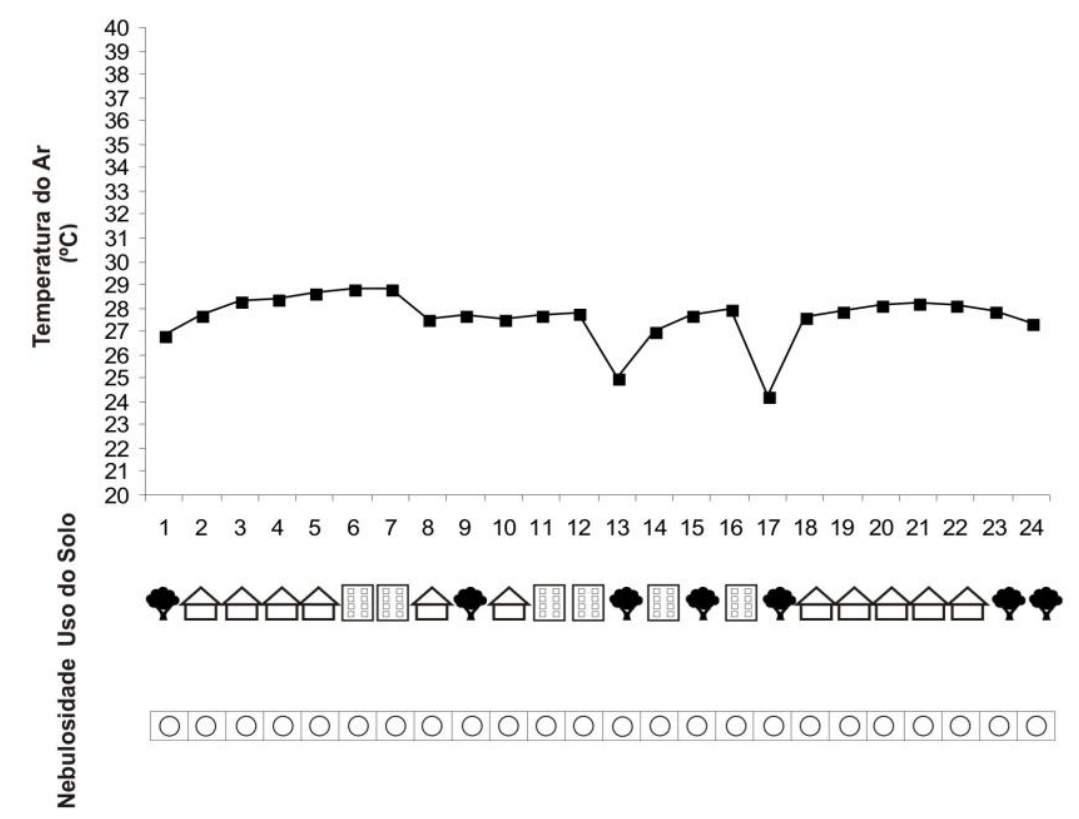

Legenda:

Temperatura do Ar

$\rightarrow$ 20:00

Nebulosidade

Céu Limpo - sem nuvens

Chuva Total Diária
$0,0 \mathrm{~mm}$

Céu Pouco Nublado - um a dois décimos encoberto

(1) Céu Parcialmente Nublado - três a quatro décimos encoberto

Sistemas Atmosféricos

Massa Equatorial Continental

Céu Quase Nublado - cinco a sete décimos encoberto

Céu Nublado - oito décimos encoberto

Densidade de Construções

Baixa Densidade de Construções $\triangle$ Média Densidade de Construções 圆Alta Densidade de Construções

Figura 11: Transecto móvel do dia 29/07/2008.

Org.: VASCONCELOS, 2010.

A Figura 12 põe em evidência os dados relativos à coleta executada no dia 30 de julho de 2008, comprovando que o tempo esteve sob a influência da Massa Tropical Continental, com céu limpo e isenção de chuvas. No tocante ao maior valor de temperatura do ar, $29,6^{\circ} \mathrm{C}$, este foi capturado no ponto 07 , que 
se inscreve na categoria de alto padrão de ocupação do solo, correspondente ao perfil de uma área comercial, com alta circulação de veículos e altitude de $242 \mathrm{~m}$.

Quanto ao menor valor de temperatura do ar, $23,8^{\circ} \mathrm{C}$, este foi apreendido no ponto 17 , inserido na categoria de baixo padrão de ocupação do solo, correspondente ao perfil de uma superfície com poucas residências, baixa circulação de veículos, muitas árvores, próxima a recursos hídricos (como córregos, lagoas etc.) e altitude de $182 \mathrm{~m}$.

Aqui, também, a amplitude térmica verificada, $5,8^{\circ} \mathrm{C}$, assegura a interferência do tipo de densidade de construções no comportamento dessa variável climática na escala local.
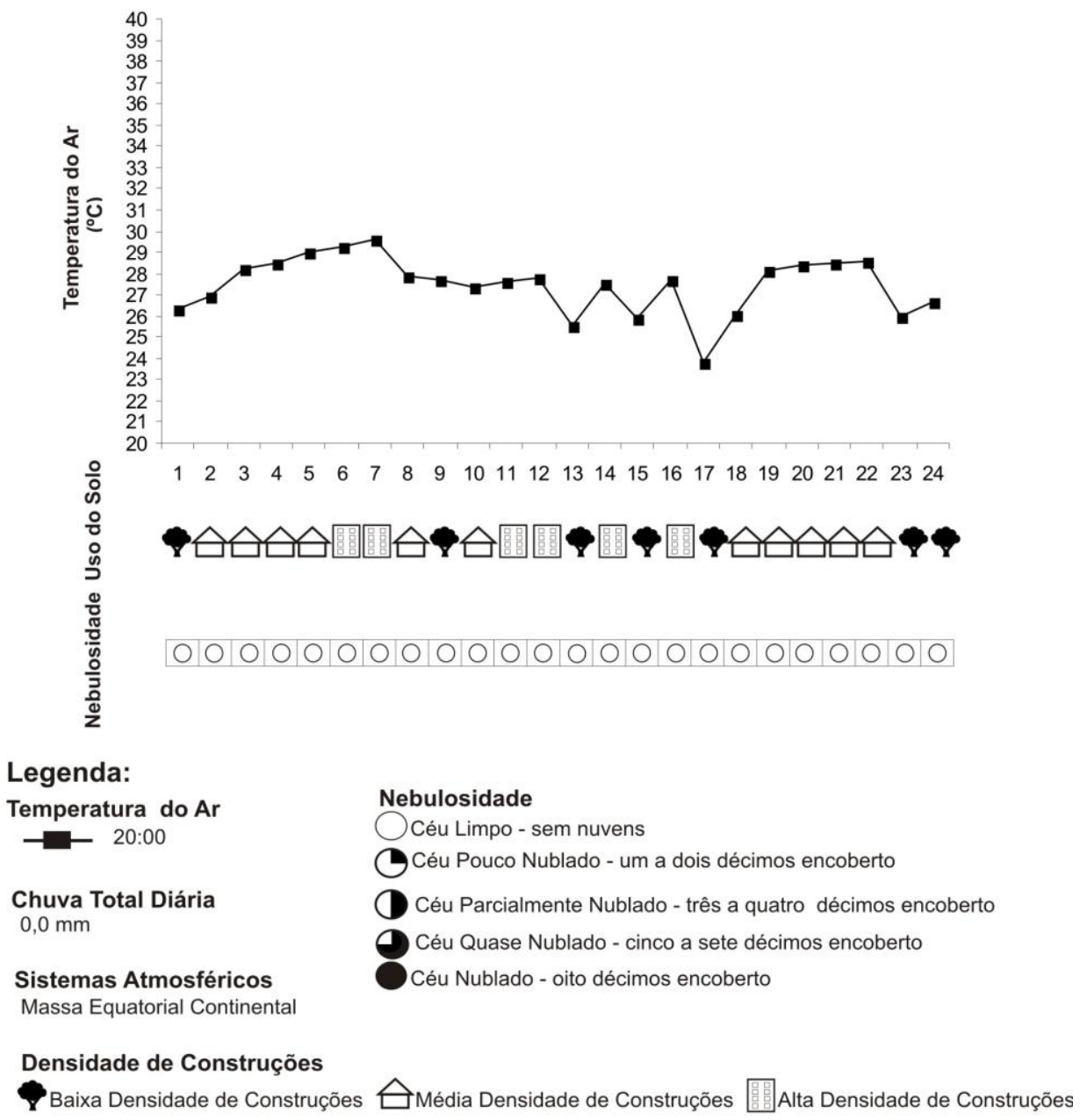
A Figura 13 apresenta os dados referentes à recolha efetuada no dia 31 de julho de 2008, constatando que o tempo esteve sob a influência da Massa Tropical Continental, com céu limpo e isenção de chuvas. Relativamente ao maior valor de temperatura do ar, $29,5^{\circ} \mathrm{C}$, este foi apreendido no ponto 07 , que se insere na categoria de alto padrão de ocupação do solo, correspondente ao perfil de uma área comercial, com alta circulação de veículos e altitude de $242 \mathrm{~m}$.

Com referência ao menor valor de temperatura do ar, $23,2^{\circ} \mathrm{C}$, este foi captado no ponto 17 , inscrito na categoria de baixo padrão de ocupação do solo, correspondente ao perfil de uma superfície com poucas residências, baixa circulação de veículos, muitas árvores, próxima a recursos hídricos (como córregos, lagoas etc.) e altitude de $182 \mathrm{~m}$.

A amplitude térmica encontrada, $6,3^{\circ} \mathrm{C}$, corrobora a interferência do tipo de densidade de construções no comportamento dessa variável climática na escala local.

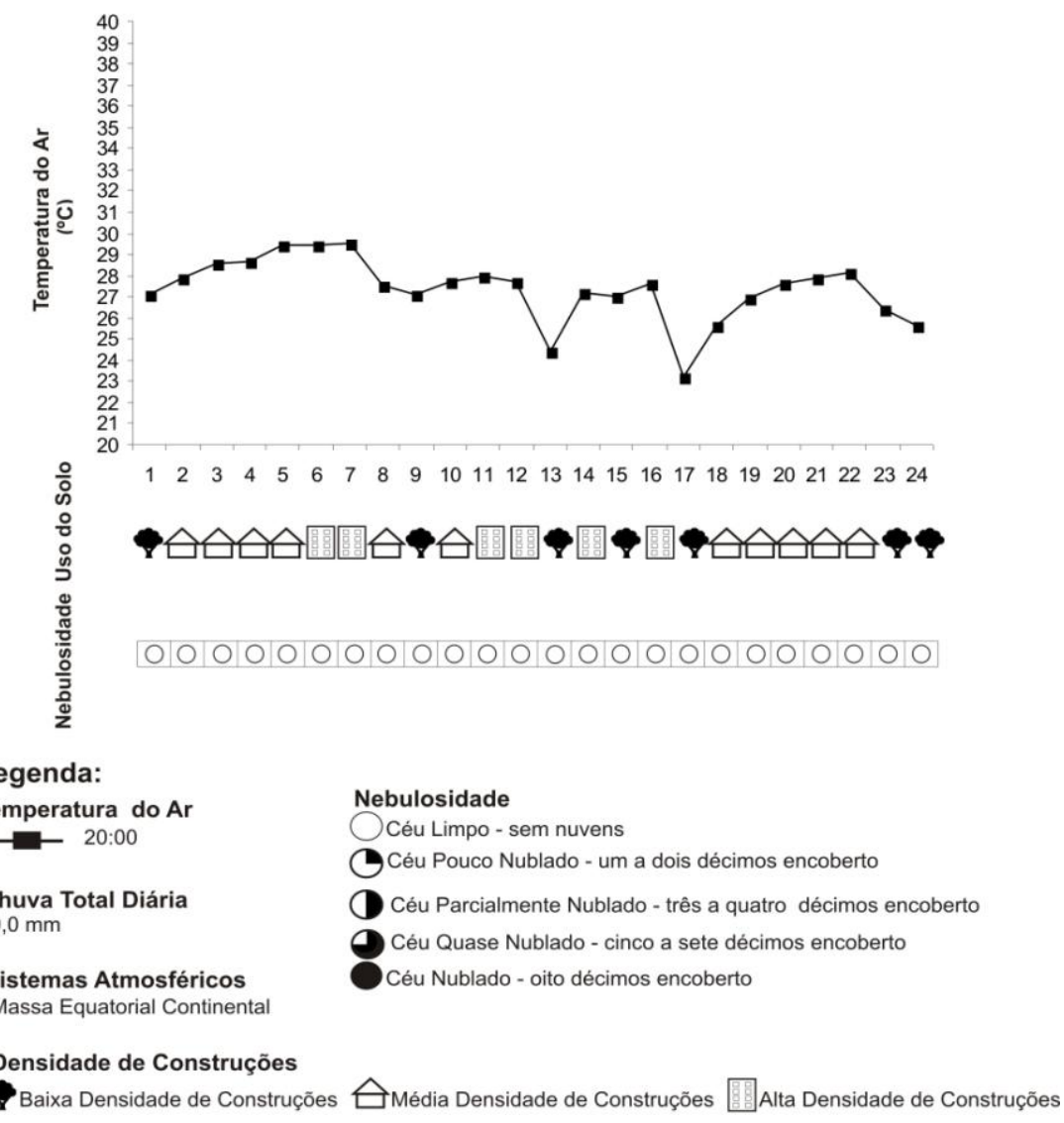

Figura 13: Transecto móvel do dia 31/07/2008.

Org.: VASCONCELOS, 2010. 
A Figura 14 expõe os dados referentes à coleta realizada no dia 01 de agosto de 2008, mostrando que o tempo esteve sob a influência da Massa Tropical Continental, com céu limpo e isenção de chuvas. O maior valor de temperatura do $\operatorname{ar}, 30,3^{\circ} \mathrm{C}$, foi detectado no ponto 07 , que se inclui na categoria de alto padrão de densidade de construções, equivalendo ao perfil de uma área comercial, com alta circulação de veículos e altitude de $242 \mathrm{~m}$.

Já o menor valor de temperatura do $\operatorname{ar}, 23,2^{\circ} \mathrm{C}$, foi registrado no ponto 17, inserido na categoria de baixo padrão de ocupação do solo, correspondente ao perfil de uma superfície com poucas residências, baixa circulação de veículos, muitas árvores, próxima a recursos hídricos (como córregos, lagoas etc.) e altitude de $182 \mathrm{~m}$.

A amplitude térmica encontrada, $6,3^{\circ} \mathrm{C}$, reafirma a interferência do tipo de densidade de construções no comportamento dessa variável climática na escala local.

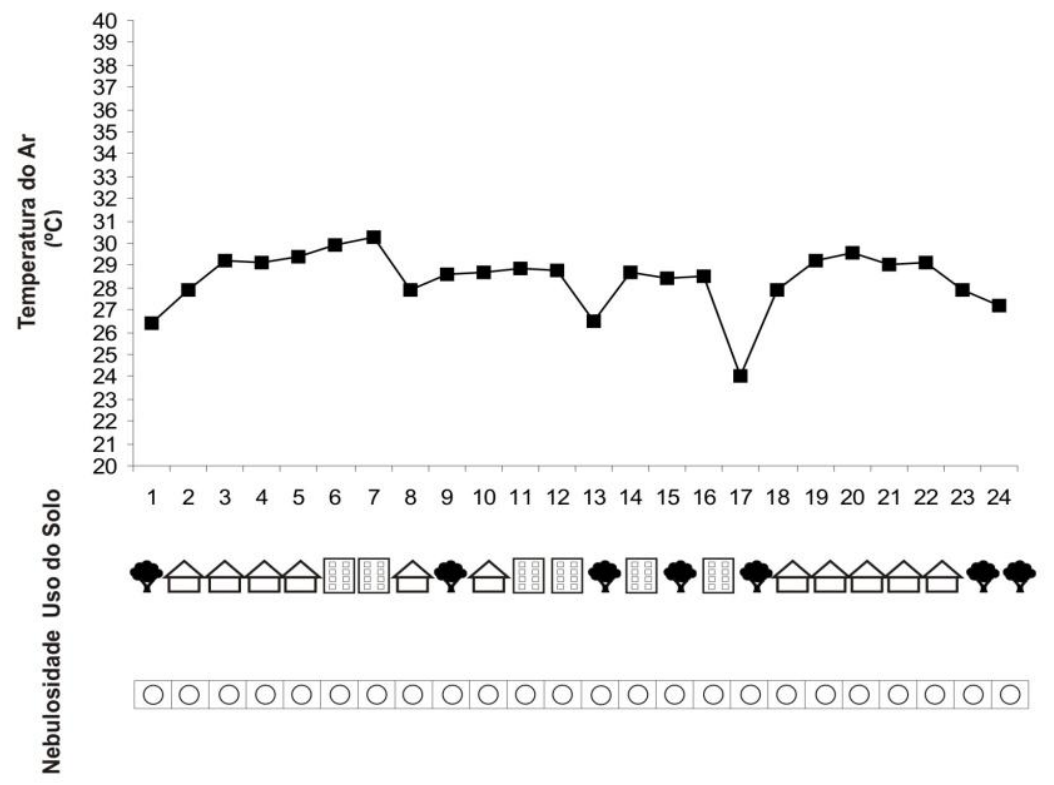

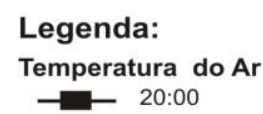

Chuva Total Diária $0,0 \mathrm{~mm}$

Sistemas Atmosféricos Massa Equatorial Continenta

Densidade de Construções

PBaixa Densidade de Construções $\triangle$ Média Densidade de Construções Figura 14: Transecto móvel do dia 01/08/2008.

Org.: VASCONCELOS, 2010.

\author{
Nebulosidade \\ Céu Limpo - sem nuvens \\ $\rightarrow$ Céu Pouco Nublado - um a dois décimos encoberto \\ (1) Céu Parcialmente Nublado - três a quatro décimos encoberto \\ Céu Quase Nublado - cinco a sete décimos encoberto \\ Céu Nublado - oito décimos encoberto
}


A Figura 15 reúne os dados levantados na coleta do dia 02 de agosto de 2008, revelando, mais uma vez, que o tempo esteve sob a influência da Massa Tropical Continental, com céu limpo e isenção chuvas. O maior valor de temperatura do $\operatorname{ar}, 30,3^{\circ} \mathrm{C}$, foi encontrado nos pontos 07 e 22 , inseridos nas categorias de alto e médio padrões de densidade de construções, equivalendo, portanto, aos respectivos perfis de uma área comercial, com alta circulação de veículos e altitude de $242 \mathrm{~m}$, sendo o outro ponto localizado numa área residencial, com média circulação de veículos e altitude de $235 \mathrm{~m}$.

Já o menor valor de temperatura do $\operatorname{ar}, 28,2^{\circ} \mathrm{C}$, foi registrado no ponto 17, inserido na categoria de baixo padrão de ocupação do solo, correspondendo ao perfil de uma superfície com poucas residências, baixa circulação de veículos, muitas árvores, próxima a recursos hídricos (como córregos, lagoas etc.) e altitude de $182 \mathrm{~m}$.

A amplitude térmica verificada, $2,1^{\circ} \mathrm{C}$, também nos permite afirmar que, na estação seca, os valores de temperatura do ar são sempre elevados, além de mostrar que a interferência do tipo de densidade de construções no comportamento dessa variável climática na escala local.
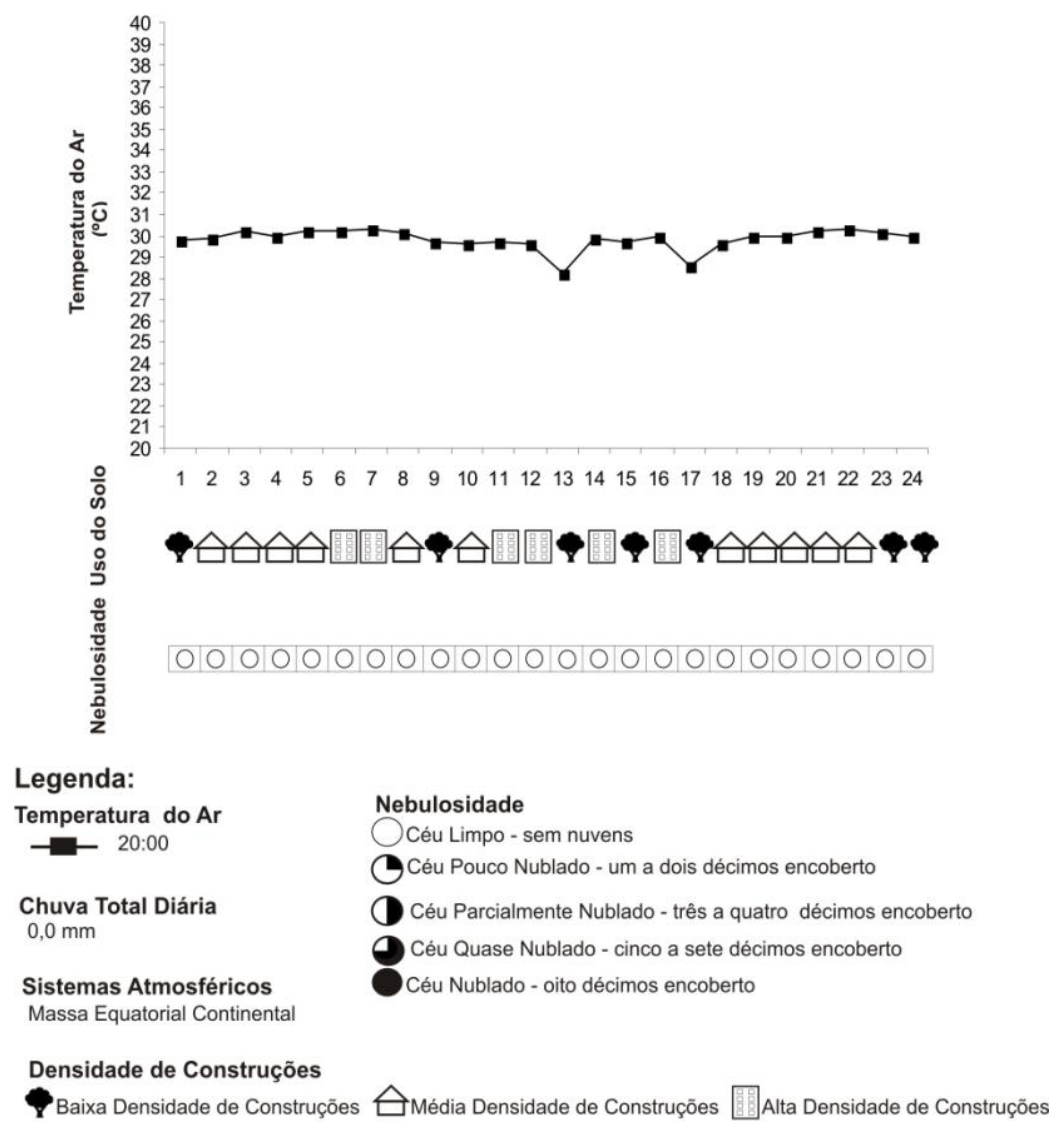

Figura 15: Transecto móvel do dia 02/08/2008.

Org.: VASCONCELOS, 2010. 
Os dados climatológicos coletados por meio do transecto móvel no período de 27 de julho a 02 de agosto de 2008, durante a estação seca, no bairro Morada da Serra, em Cuiabá-MT, mostram a relação aos padrões de densidades de construções diferenciados e o comportamento rítmico das variáveis temperatura do ar, nebulosidade, total diário de chuvas e sistema atmosférico, sempre às $20 \mathrm{~h}$.

Diante disso, a análise dos dados do clima na estação seca mostrou haver certa uniformidade no comportamento das variáveis climatológicas, em especial das temperaturas do ar, que apresentaram altos valores.

Também se pôde perceber que, no período analisado, ocorreram coincidências e repetições de situações, nas quais um mesmo ponto, representando diferentes padrões de densidade de construções, explicitou a associação entre altas temperaturas e altas densidades de construções e entre baixas temperaturas e baixas densidades de construções, tanto em lugares com alta altitude quanto em lugares com baixa altitude. Verificou-se, ainda, que, no intervalo de tempo focalizado, o sistema atmosférico foi marcado pela presença da Massa Tropical Continental, com céu limpo e ausência de chuvas.

Essas condições de estabilidade implicam nitidamente a influência da radiação solar sobre o comportamento dos diferentes materiais de construção ou da natureza, que interferem nas mudanças de variáveis climáticas, como a temperatura do ar, na escala local. E, em decorrência disso, lembremos um hábito comum dos cuiabanos e, por extensão, dos moradores do bairro Morada da Serra, que, à noite, tirando proveito da temperatura mais amena, transportam cadeiras para as calçadas de suas casas a fim de conversar.

Analisando-se os dados referentes à amplitude térmica, nota-se que a maior foi de $6,3^{\circ} \mathrm{C}$, nos dias 31 de julho e $1^{\circ}$ de agosto, e a menor, $2,1^{\circ} \mathrm{C}$, no dia 02 de agosto, podendo esta última ocorrência ser explicada através da atuação da frente fria no dia 03 de agosto, provocando chuvas na cidade.

\section{CONSIDERAÇÕES FINAIS}

Nesta pesquisa, focalizaram-se os atributos dos padrões de densidades de construções do bairro Morada da Serra, em Cuiabá-MT, e suas 
implicações no comportamento de certas variáveis climáticas, avaliadas em alguns períodos das estações chuvosa (fevereiro/2008) e seca (julhoagosto/2008).

A análise revelou o ritmo das variáveis climáticas na localidade, e os dados coletados no transecto móvel relativamente à estação chuvosa foram examinados na perspectiva da atuação destes sistemas atmosféricos: as massas Tropical Continental e Equatorial Continental. Por outro lado, os dados colhidos no transecto móvel referentes à estação seca foram analisados à luz da atuação da Massa Tropical Continental, que gerou altas temperaturas.

$\mathrm{Na}$ coleta dos dados ocorridas sempre às $20 \mathrm{~h}$, durante as estações seca e chuvosa, destacaram-se os pontos 07 e 17 como aqueles nos quais se registraram, respectivamente, altos índices de densidade de construções e os maiores valores de temperatura do ar e baixos índices de densidade de construções e os menores valores de temperatura do ar.

Esses resultados provavelmente são reveladores da interferência da densidade de construções no comportamento dessa importante variável climática na escala local, em função do que se pode afirmar que as áreas verdes são insuficientes para amenizar as altas temperaturas na área em estudo. Além disso, outras variáveis climáticas, como nebulosidade, chuva e sistema atmosférico, podem sobrepor-se à densidade de construções.

Dessa forma, todos nós, sociedade e governo, temos responsabilidades com relação à problemática tratada neste trabalho. Como cidadãos, devemos estabelecer mudanças de paradigmas já em nossas próprias casas, mantendo árvores nos quintais, por exemplo. Além disso, precisamos acompanhar e discutir, nas instâncias de decisões públicas, as políticas públicas que produzem as modificações referentes aos padrões de densidade de construções implementadas pelos órgãos de planejamento das cidades. 


\section{REFERÊNCIAS BIBLIOGRÁFICAS}

BUCCHERI FILHO, Alexandre Theobaldo; NUCCI, João Carlos. Espaços Livres, Áreas Verdes e Cobertura Vegetal no Bairro Alto da XV, Curitiba/PR. Revista do Departamento de Geografia. São Paulo - SP, n. 18, 2006. p. 4859.

COELHO, Maria Célia Nunes. Impactos Ambientais em Áreas Urbanas: Teorias, Conceitos e Métodos de Pesquisa. In: GUERRA, António José Teixeira; CUNHA, Sandra Baptista (orgs.). Impactos Ambientais Urbanos no Brasil. 2 ${ }^{a}$ ed. Rio de Janeiro: Bertrand Brasil, 2004.

INSTITUTO Nacional de Pesquisas Espaciais / Centro de Previsão de Tempo e Estudos Climáticos (INPE/CPTEC). Carta Sinótica de Superfície. Cachoeira Paulista - SP, 2009. Disponível em: http://www.cptec.inpe.br/tempo. (Acesso em dez. 2009).

INSTITUTO Nacional de Pesquisas Espaciais / Divisão de Satélites e Sistemas Ambientais (INPE/DSA). Imagens de Satélites - GOES 10. Cachoeira Paulista - SP, 2009. Disponível em: http://satelite.cptec.inpe.br/home. (Acesso em dez. 2009).

MONTEIRO, Carlos Augusto de Figueiredo. Teoria e Clima Urbano. São Paulo: Instituto de Geografia - Universidade de São Paulo, 1976. (Série Teses e Monografias, 25)

MORENO, Gislaene. A Colonização no Século XX. In: MORENO, Gislaene; HIGA, Tereza Cristina Souza (orgs.). Geografia de Mato Grosso: Território, Sociedade, Ambiente. Cuiabá: Entrelinhas, p. 52-71, 2005.

ROMANCINI, Sônia Regina. Pedra 90: Meio Ambiente Urbano e Educação. Cuiabá-MT: UFMT. Dissertação (Mestrado em Educação), Instituto de Educação, Universidade Federal de Mato Grosso, 1996.

SANTOS, Milton; SILVEIRA, Maria Laura. O Brasil - Território e Sociedade no Início do Século XXI. Rio de Janeiro: Record, 2001. 